\title{
Bio-efficacy of acaricides against two spotted spider mite, Tetranychus urticae Koch (Acarina: Tetranychidae) infesting carnation (cv. Beaumonde) under protected cultivation
}

\author{
DINESH L. PATIL ${ }^{* 1}$, K.A. PATEL ${ }^{2}$, N.R. TOKE ${ }^{1}$ AND ARCHANA T. AMBULE ${ }^{1}$
}

${ }^{1}$ Department of Entomology, N.M. College of Agriculture, Navsari Agricultural University, NAVSARI (GUJARAT) INDIA

${ }^{2}$ Main Sorghum Research Station, Navsari Agricultural University, SURAT (GUJARAT) INDIA

\section{ARITCLE INFO}

$\begin{array}{ll}\text { Received } & : 31.03 .2014 \\ \text { Revised } & : 27.08 .2014 \\ \text { Accepted } & : 08.09 .2014\end{array}$

\section{KEY WORDS :}

Tetranychus urticae, Carnation, Acaricides

\begin{abstract}
The acaricides tested for the bio-efficacy against Tetranchyus urticae under polyhouse conditions revealed that all the acaricidal treatments were significantly superior to untreated control in checking the mite population under polyhouse conditions. Among acaricides, propargite 0.05 per cent gave 69.19 per cent mite population reduction after two application. The next best treatment in order of effectiveness was abamectin 0.0025 per cent $(63.34 \%)$ and it also exhibited consistent performance as second best treatment, followed by dimethoate 0.03 per cent $(57.97 \%)$. However, the benefit cost ratio showed that propargite and dimethoate were most economical with net BCR of 1: 8.98 and 1: 8.93 , respectively and gave effective control of T. urticae.
\end{abstract}

How to view point the article : Patil, Dinesh L., Patel, K.A., Toke, N.R. and Ambule, Archana T. (2014). Bio-efficacy of acaricides against two spotted spider mite, Tetranychus urticae Koch (Acarina: Tetranychidae) infesting Carnation ( $c v$. Beaumonde) under protected cultivation. Internat. J. Plant Protec., 7(2) : 429-432. 